MARIA WTORKOWSKA

WYDZIAL FILOZOFICZNY

UNIWERSYTET W LUBLANIE

LUBLANA, StoWENIA

mwtorkowska@yahoo.com

https://doi.org/10.17234/9789531755139.35

\title{
JĘZYKOWY OBRAZ ŚWINI I JEJ RODZINY PRZEZ PRYZMAT FRAZEOLOGII W JĘZYKU POLSKIM I SŁOWEŃSKIM
}

\begin{abstract}
Artykuł poświęcony jest frazeologii porównawczej. Porównano w nim polskie związki wyrazowe, głównie frazeologizmy z komponentem świnia/svinja i innymi przedstawicielami rodziny świni ze związkami wyrazowymi występującymi w języku słoweńskim. W efekcie analizy związków uzyskano cechy charakterystyczne, które człowiek przypisuje świni i członkom jej rodziny. Przyjrzano się również użyciom i znaczeniom przenośnym tych wyrazów w obu językach.
\end{abstract}

Słowa kluczowe: frazeologia porównawcza, glottodydaktyka polonistyczna, język polski jako obcy (JPJO), język stoweński

W języku polskim i słoweńskim, podobnie jak w innych językach, istnieje szereg związków wyrazowych z komponentem odzwierzęcym. Wśród zwierząt domowych ważne miejsce, tak w polskiej, jak i słoweńskiej frazeologii, zajmuje świnia i jej rodzina, która w Uniwersalnym słowniku języka polskiego definiowana jest jako 'zwierzę domowe o skórze pokrytej szczeciną, dużej głowie i pysku tworzącym ryj, wydające charakterystyczne odgłosy, np. pochrząkiwania lub kwik; hoduje się je dla mięsa, tłuszczu i skór' (USJP' III: 1608), a w Słowniku słoweńskiego języka literackiego jako 'samica prašiča' (SSKJ: 1341), prašič zaś jako 'domača žival, ki se goji zlasti zaradi mesa in slanine' (SSKJ: 966), tj. zwierzę domowe hodowane dla mięsa i słoniny. Tak polskie jak i słoweńskie wyjaśnienia słownikowe są więc podobne w tym, że oba zwracają uwagę na podstawowy cel ich hodowli, z tą jednak wyraźną różnica, że definicja polska zawiera również dość dokładny opis świni: skóra pokryta szczeciną, duża głowa, pysk tworzący ryj oraz informację o dźwięku, jaki wydaje świnia: pochrząkiwanie lub kwik. W definicji słoweńskiej, która w formie rozwiniętej dotyczy nie leksemu svinja, ale prašič, tych danych brak, a informacja o dźwięku wydawanym przez świnię zawarta jest poza samym wyjaśnieniem znaczenia: prašič cvili, kruli, tj. świnia chrząka, kwiczy.

Co tak naprawdę świnia i jej rodzina znaczy czy znaczyła w życiu człowieka Polaka i Słoweńca - możemy sprawdzić analizując polskie i słoweńskie związki wy-

Skróty słowników zamieszczone są przy ich pełnych tytułach w spisie literatury. 
razowe z nimi powiązane oraz zakresy użycia tych wyrazów w obu językach. Polskie związki wyekscerpowałam ze Stownika frazeologicznego języka polskiego Stanisława Skorupki oraz Uniwersalnego stownika języka polskiego pod redakcją Stanisława Dubisza. Słoweńskich związków wyrazowych szukałam w nowym, wydanym w 2011 r., Stowniku stoweńskich frazemów Janeza Kebera oraz książce Živali v prispodobah jego autorstwa, jak również w Słowniku stoweńskiego jezzyka literackiego.

Przedstawicielami rodziny świni są w języku polskim świnia, maciora, locha, wieprz, knur, tucznik, młode: świnka, prosię, prosiak, wieprzek, świniak, warchlak, w języku słoweńskim zaś prašič, svinja, prase, prasec, merjasec, młode: prašiček, prasička, pujs, pujsek. Wszystkie te określenia są ważne, ponieważ czasem używane są wymiennie w tych samych związkach wyrazowych, inne zaś nie wchodzą w skład związków, przyjrzyjmy się na przykład wyrażeniu porównawczemu jeść jak świnia albo jeść jak prosię, o jednakowym znaczeniu 'jeść brzydko, niechlujnie, nieestetycznie' (USJP III: 1608), czy zachowywać się / zachować sie jak świnia lub zachowywać się / zachować się jak prosię o tym samym znaczeniu 'postępować / postapić podle, nieprzyzwoicie wobec kogoś, zwłaszcza wobec osoby bezbronnej lub takiej, której się coś zawdzięcza' (USJP III: 1608), z tą jednak różnicą, że prosię jest użyte w tych dwóch wyrażeniach eufemistycznie. Ponieważ prosię oznacza młode świni i ma przez to łagodniejszy wydźwięk, nie ma takiej mocy wyrazu jak dorosła świnia o wydźwięku silnie pejoratywnym.

W związku z tym, że świnia żyje, przebywa najczęściej w brudnych pomieszczeniach i bez ustanku je, nie dziwi fakt, że ludziom kojarzy się zazwyczaj negatywnie. Poza tym świnie hoduje się - jak możemy wyczytać w jej definicjach słownikowych - głównie dla mięsa, a nie do celów pociagowych, czy pracy w polu, jak na przykład konie, krowy, dlatego kontakt świni z człowiekiem pozostaje ograniczony w zasadzie tylko do jej karmienia w chlewie, co nie sprzyja rozwojowi przyjacielskich stosunków człowieka ze świnią. Świnie się karmi, aby je utuczyć, a następnie zabić i uzyskać jak najwięcej mięsa, tłuszczu i skóry.

Zarówno w języku polskim, jak i słoweńskim świna utożsamiana jest z brudem. W języku polskim mamy wyrażenie porównawcze ktoś (jest) brudny (upaprany itp.) jak świnia w znaczeniu 'ktoś (jest) bardzo brudny' (USJP III: 1608) lub same wyrazy prosię, prosiak oznaczające młodą świnię na określenie człowieka niechlujnego, nieporządnego, niedbałego, w słoweńskim zaś podobnie svinja, prasec lub prasica (kakšna svinja si, umij se; umiti moram tega prasca; kakšna prasica pa si) o ograniczonym znaczeniu 'umazan človek', tj. brudny człowiek. Ponieważ osobami, które często brudzą siebie, innych i okolicę są dzieci, w stosunku do nich używa się wyrazów zdrobniałych, a więc określeń pieszczotliwych, czy żartobliwych typu świnka, prosiatko, podobnie jak w języku słoweńskim prašiček (umiti moram tega prašička) czy pujsek (sosedov fant je pujsek; umij se, pujsek). Użycie wobec dzieci określeń niezdrobniałych typu świnia, prosię, czy pujs odczuwane jest jako wyraźnie pejoratywne i niestosowne. Porównajmy na przykład słow. pujs, choć jest pieszczotliwym określeniem prašiča, użyty w stosunku do dziecka w znaczeniu 'brudny człowiek, zwłaszcza dziecko' jest obraźliwe: 
umiti moram tega pujsa (SSKJ: 1096). Podobnie jak prosię (USJP III: 585), choć oznacza młodą świnię. $Z$ niewłaściwym zachowaniem człowieka w towarzystwie związane są zwroty rymowane z odmiany mówionej języka, najczęściej spotykane wśród dzieci, typu nie dlub w nosie, boś nie prosię, czy tylko prosię dlubie w nosie.

Pozytywną konotację mają w obu językach formy deminutywne nazw istot młodych tego gatunku: prašiček, pujsek i świnka, prosiak, prosiaczek, prosiatko. Używa się ich jako żartobliwych spieszczeń, skierowanych przede wszystkim do małych dzieci.

Drugą właściwością przypisywaną świni jest grubość. W języku polskim znajdziemy potoczne, pospolite wyrażenie porównwcze gruby (tlusty, spasiony) jak wieprz (USJP IV: 432), które używane jest na określenie kogoś bardzo grubego, otyłego, opasłego, w języku słoweńskim także występuje wyrażenie porównawcze debel kot prašič (SSKJ: 966), czyli bardzo gruby. W potocznym języku mówionym w obu językach słychać też w tym znaczeniu wyrażenia porównawcze z wyrazem świnia: gruby (tlusty) jak świnia i svinja: debel kot svinja, choć słowniki ich nie odnotowują. Z grubością wiąże się nadmierne jedzenie, stąd zwrot w języku polskim obżerać się jak świnia (SFJP II: 332), czyli bardzo dużo jeść, jeść ponad miarę.

Świnia przebywa głównie w chlewie, gdzie przede wszystkim śpi i je, nie jest wypuszczana na zewnątrz, można więc powiedzieć, że nie robi nic pożytecznego. Jest więc leniwa, co można powiązać też z jej grubością i czego wyrazem jest słoweńskie wyzwisko prasica lena, to jest leniwa świnio! W odmianie mówionej języka polskiego można usłyszeć zwrot gnić jak świnia, a więc nic nie robić, tylko się wylegiwać, nie być pożyteczny.

Ze świnią wiąże się również nikczemność, nieetyczność, niemoralność, mało- lub bezwartościowość. Te negatywne cechy uwidoczniają się w polskim związku z kogoś wyszło prosię o znaczeniu 'ktoś zachował się w jakiejś sytuacji nieetycznie, niemoralnie, nikczemnie, podle' (USJP III: 585). Podobne znaczenie z komponentem wymiennym mają potoczne związki porównawcze: zachowywać się / zachować się jak świnia, czy zachowywać się / zachować się jak prosię (USJP IV: 753). Związek z elementem prosię, oznaczającym młode świni, ma łagodniejszy, eufemistyczny wydźwięk. Etyczna nieprzyzwoitość, niemoralność ukrywa się we frazeologizmie potocznym podlożyć komuś świnię, co oznacza 'intrygując spowodować, że ktoś znajdzie się w sytuacji, która mu zaszkodzi, skompromituje go' (USJP III: 1608) lub też być (okazać się, zostać) świniq (SFJP II: 332), czyli 'być niekoleżeńskim, postąpić nieetycznie', czy też postapić jak świnia, postapić po świńsku, to znaczy 'postąpić nieetycznie'. W języku słoweńskim występuje związek delati (ravnati) s kom, s čim kot svinja z mehom (SSF: 938-939), to jest postępować $z$ kimś, z czymś jak świnia z miechem w znaczeniu 'postępować z kimś, z czymś źle, niedbale, traktować kogoś, coś źle, powierzchownie'.

W obu językach możliwe jest pogardliwe, obraźliwe określenie człowieka podłego, nikczemnego, takiego, który wyrządził komuś krzywdę, zrobił świństwo, a więc drania, szuję, mianem świnia (Z kogoś jest kawat świni. Ty świnio!), czy łagodniejszym, czasem w użyciu żartobliwym prosię (Nie badź prosię, oddaj to, co pożyczyteś!), w języku słoweńskim zaś pojawia się więcej możliwości, gdyż prawie wszystkie określenia 
członków rodziny świni i jej nazwy synonimiczne, a więc svinja, prase, prasec, prašič, prašiček, prasica, prasička, mogą być użyte na pogardliwe określenie bezwartościowego, czy małowartościowego człowieka, porównajmy przykłady: ta človek je čisto navadna, prava svinja, to prase mu ni dalo miru, kateri prasec jih je izdal, daj mir, prašič nemarni, kakšen si, prašiček nemarni, ti nisi prijatelj, prasica si, je prava prasička.

Niewłaściwe, niekulturalne zachowanie świni przedstawiają pospolite zwroty porównawcze jeść jak świnia i jeść jak prosię, czyli 'jeść brzydko, niechlujnie, nieestetycznie' (USJP I: 1296). Z niewłaściwym, nieeleganckim zachowaniem, brakiem kultury związany jest również polski frazeologizm odejść jak świnia od koryta (SFJP II: 332), czyli bez podziękowania, bez słowa oraz ktoś lezie (pcha się itp.) jak świnia do koryta (USJP III: 1608), czyli ktoś jest natrętny, niedelikatny, ktoś chce dostać się gdzieś siłą (odpowiedników tych frazeologizmów brak w języku słoweńskim) czy wyrażenie prosię nieskrobane (SFJP II: 753) na określenie prostaka, gbura, grubianina. Pasać / paść z kimś świnie - nie pasać / nie paść z kimś świń (USJP III: 1608; SFJP II: 332 ) to zwroty, które mogą być skierowane do osoby, pozwalającej sobie na nadmierną poufałość, do której nie jest ona upoważniona (najczęściej w formie: świń z tobq (z nim itp.) nie pastem / nie pasalem). W zaprzeczonej formie oznaczają, że kogoś nie znamy zupełnie, że jesteśmy dla kogoś obcy. Zwrot ten często może również wskazywać na różne pochodzenie społeczne osób. Forma niezaprzeczona oznacza, że znamy kogoś dobrze, jesteśmy z nim w zażyłych, poufałych stosunkach, mimo różnic pochodzenia. $\mathrm{W}$ języku słoweńskim funkcjonuje podobny zwrot, jednak występuje w nim nie świnia, lecz krowa - [saj] nisva krav skupaj pasla, (kot da) sva krave skupaj pasla? 'nisva enaka, iste starosti, izobrazbe' (SSF 2011: 402), tj. nie jesteśmy sobie równi, nie jesteśmy rówieśnikami, nie mamy tego samego wykształcenia. Zwrot ten może występować podobnie jak w języku polskim zarówno w formie twierdzącej, jak i zaprzeczonej.

Niewłaściwe zachowanie wiąże się również z nieumiarkowanym piciem alkoholu, stąd określenia porównawcze, które obrazują przypisywane świni pijaństwo: pijany (spity) jak świnia, 'być bardzo, zupełnie, kompletnie pijany, pijany do nieprzytomności', spić się (upić się, schlać się, urżnqú się) jak świnia, w znaczeniu 'bardzo się upić, upić się do utraty przytomności' (USJP III: 1608). Zwrotu leżeć jak świnia (SFJP II: 332) używa się w odniesieniu do człowieka leżącego w stanie pijanym. W języku słoweńskim jest wulgarny związek frazeologiczny pijan kot svinja 'zelo pijan', tj. bardzo pijany. Ciekawy jest polski związek ktoś (jest) trzeźwy jak świnia o znaczeniu przeciwnym, a więc 'ktoś nie jest pijany, ktoś jest zupełnie trzeźwy; o kimś zupełnie trzeźwym, niebędącym pijanym' (USJP III: 1608).

Polska świnia potrafi być też głośna, o czym świadczy frazeologizm kwiczeć jak zarzynane prosię (USJP III: 585; SFJP II: 753). Znaczenie tego związu jest głośno krzyczeć, zwykle z bólu. Język słoweński podobnego zwrotu nie odnotowuje.

Nieprzyzwoitość może być powiązana również z niestosownym, niewłaściwym, agresywnym słownym zachowaniem mężczyzn w stosunku do kobiet. Mężczyźni ci są zazwyczaj otyli, a nieprzyzwoitość zachowania ma podtekst seksualny, erotyczny. Zachowania te mogą mieć również charakter agresywny, brutalny i mogą być 
związane z użyciem siły, przemocy. Mężczyznę, często grubego, który zachowuje się nieprzyzwoicie, jest skłonny do obscenicznych żartów, gestów określa się mianem świnia, wieprz (Ty świnio, nie podgladaj! Precz z tapami, stary wieprzu!), czy łagodniej prosię, prosiak, w języku słoweńskim zaś prašič, merjasec w znaczeniu 'pohoten, nasilen moški', tj. pożądliwy, lubieżny, rozpustny, agresywny, napastliwy, brutalny mężczyzna (Stari prašič jo je spet nadlegoval. Čvekanje nerodnega merjasca.). Jako wyzwisko w odniesieniu do mężczyzn w języku słoweńskim funkcjonuje najczęściej wyraz prasec lub svinja, w stosunku do kobiet zaś najczęściej prasica.

O głupocie i bezmyślności świni świadczy związek zaczerpnięty z Biblii - w języku polskim jest to rzucać perly przed (między) wieprze (SFJP II: 561), rzucać perly przed wieprze (USJP III: 96), rzucać perly przed świnie (SFJP II: 332; Mat. VII, 6) przed słoweńskim metati bisere svinjam (SSF: 77) w znaczeniu 'dawać komuś coś, czego ten ktoś nie potrafi docenić. Polski zwrot rozmawiać z kimś jak gesś z prosięciem (USJP I: 1003; SFJP II: 753) w znaczeniu 'rozmawiać z kimś, nie rozumiejąc się nawzajem' ma kulturowe uwarunkowanie - pochodzi z wiersza Jana Brzechwy, w którym autor podkreśla głupotę gęsi, prosię natomiast okazuje się rozsądne w swych argumentach. W języku polskim o kimś głupim, nierozgarniętym, kto powinnien znaleźć się na innym stanowisku pracy lub zając się czymś innym, powie się, że świnie powinien (powinna) paść / pasać (SFJP II: 332). Zwrot ten ukazuje również jak poniżający był zawód pasterzy świń, który nie wymagał dużych umiejętności, a zwłaszcza bystrości umysłu.

$\mathrm{W}$ języku słoweńskim znajdziemy zwrot, którego nie ma w języku polskm: biti trinajsto prase, tj. być trzynastym prosięciem lub jako wyrażenie porównawcze kot trinajsto prase, tj. jak trzynaste prosię, czy sam związek trinajsto prase (SSF: 745-746), tj. trzynaste prosię. Związki te wywodzą się z fizjologicznej cechy świni, a mianowicie faktu, że posiada dwanaście sutków. Po przyjściu na świat każde prosię wybiera sobie swój sutek, ewentualne trzynaste prosię pozostaje bez mleka, a więc nie ma możliwości przeżycia. W znaczeniu przenośnym używa się tych związków na określenie kogoś, kto jest zbędny, niepotrzebny lub czegoś, co jest niepotrzebne. Związkiem synonimicznym byłoby tu występujące w obu językach piate koło u wozu - biti (za) peto kolo, czy występujący tylko w języku polskim związek potrzebny jak dziura w moście.

Zarówno w języku polskim, jak i słoweńskim używa się wyrazu świnia i jej członków rodziny, najczęściej z odpowiednią przydawką określającą jako wyzwiska (słow. psovka), porównajmy pol. świnia: Ty (stara) świnio!, Ty świnio jedna! Świnie jedne!, Z ciebie jest kawat świni!, wieprz: Ty stary wieprzu!, svinja: izdajalska svinja, Kaj bi rad, svinja pijana?, prašič: Daj mir, prašič nemarni!, prase: prekleto prase, prasec: prekleti prasec, prasica: prasica lažniva, merjasec: Mir mi daj, merjasec! Również młodzi członkowie świńskiej rodziny, jak i ich pieszczotliwe określenia mogą występować w funkcji wyzwisk, np. prosię: Nie bądź prosię, oddaj!, prašiček: Kakšen si, prašiček nemarni!, pujs: ti pujs nemarni.

Wulgarnie jest nacechowany słoweński zwrot pristati (podati se) komu kot svinji sedlo (SSF: 938-939), czyli pasować do kogoś jak siodło do świni, z możliwością wymiany świni na krowę (podati se komu kot kravi sedlo) o znaczeniu 'być niestosowny, 
niewłaściwy, nieodpowiedni'. W języku polskim semantycznym odpowiednikiem jest związek coś, ktoś pasuje, nadaje się do czegoś jak wót do karety (USJP IV: 497), o znaczeniu 'coś, ktoś nie pasuje, nie nadaje się zupełnie do kogoś lub czegoś'.

Leksem świnia występuje również w nazwach gier. Przykładem tego jest w języku polskim nazwa prostej gry w karty świnka, która polega na dokładaniu do odkrytej karty innej tego samego koloru, wyszukiwanej spośród kart rozłożonych i zakrytych (USJP: 1609), znana również pod nazwą gra w świnie, czy słoweńskie wyrażenie svinjo zbijati, tj. zbijać świnię na określenie gry dziecięcej, polegającej na rzucaniu kamieni w stojący przedmiot w celu jego przewrócenia. Gra była rozpowszechniona w całej Słowenii i funkcjonowała pod różnymi nazwami (Keber 1996: 334), choć młodsze pokolenie jej już raczej nie zna.

Wiele cech charakterystycznych dla świni i jej rodziny ukrytych jest również w przymiotnikach: polskim świński (USJP III: 1609; SFJP II: 332) i słoweńskich svinjski (SSKJ: 1341), prašičji (SSKJ: 966). W języku polskim przymiotnik świński oznacza 'nieuczciwy, pełen niegodziwości; podły', na przykład świński charakter, świński postępek lub 'mówiący o sprawach seksu w nieprzyzwoity, obsceniczny sposób; sprośny', na przykład świński dowcip, świński film. Przymiotnik świński jest też komponentem w związkach frazeologicznych: świńskie oczka 'oczy człowieka bardzo małe, w zbyt jasnej oprawie', czy w wyrażeniu: świński blondyn 'mężczyzna o bardzo jasnych, prawie białych włosach, brwiach, rzęsach i zaroście' lub zwrocie: biec / pobiec świńskim truchtem 'biec / pobiec drobnymi kroczkami, truchcikiem'. W języku polskim przymiotnik ten występuje też jako określenie wyrazów ryj, morda, łeb w funkcji wulgarnego wyzwiska: świński ryj, świńska mor$\boldsymbol{d a}$, świński leb, służy więc do fizycznego opisu ludzi lub ich zachowań i ma zazwyczaj negatywny wydźwięk. Przymiotnik svinjski w języku słoweńskim znaczy 'brudny' (Kako svinjske roke imaš!), czego nie ma w języku polskim, jak również 'nespodoben, opolzek', tj. 'nieprzyzwoity, obleśny' (poslušati svinjske šale). W użyciu ekspresywnym wskazuje również na stopień dużej intensywności zjawiska, o którym mowa, np. Pritisnil je svinjski mraz. Nastopila je svinjska vročina. tj, cholerny mróz, cholerny gorąc, czego nie odnotowuje z tym komponentem polszczyzna. Negatywne znacznie ma określenie svinjski również w następujących związkach występujących tylko w języku słoweńskim: biti svinjski do koga (być świński w stosunku do kogoś) 'hudoben, zloben', tj. zły, złośliwy, imeti svinjski dan (mieć świński dzień) 'naporen, težek', tj. ciężki, uciążliwy, svinjsko vreme (świńska pogoda) 'slabo, neugodno', tj. brzydka, niesprzyjająca. Janez Keber (1996: 335) odnotowuje wyrażenie prašičje oči 'majhne, podolgovate oči', choć nie jest ono rozpowszechnione i ogólnie znane.

Ciekawy jest słoweński zwrot imeti svinjsko srečo (SSF: 939; SSKJ: 1341) (dosł. mieć świńskie szczęście) o znaczeniu 'mieć wielkie, nieoczekiwane szczęście, szczególnie w nieprzyjemnych, niekorzystnych okolicznościach', co wskazuje na jakąś pozytywną cechę związaną ze świnią. Podobnie pozytywny wydźwięk ma w języku polskim wyrażenie porównawcze szczęśliwy (zadowolony, wesoby, pobożny, tadny) jak świnia (prosię) w deszcz, zaczerpnięte ze Stownika mitów i tradycji kultury (SMTK: 1161). 
Podsumowując, świnia oraz jej określenia synonimiczne i nazwy członków rodziny tego gatunku, mają podobne cechy w obu językach. Cechy te są w większości pejoratywne: świnia jest brudna, gruba, leniwa, głupia, bezmyślna, pijana, głośna, bezwartościowa, zachowuje się nieetycznie, niemoralnie, nieprzyzwoicie. Nazwy wszystkich członków rodziny świni w języku polskim i słoweńskim mogą występować w funkcji wyzwisk. Charakteryzowanie człowieka za pomocą nazw zwierząt jest zjawiskem częstym i, jak wynika z badań $R$. Tokarskiego, ukierunkowanym znacznie częściej na przedstawienie wartościujące ujemnie (Tokarski 1990: 74), co potwierdza również niniejsza analiza polskich i słoweńskich związków z komponentem świnia i jej nazwami synonimicznymi. Maria Peisert w swoich rozważaniach na temat świni również stwierdza, że „żadne inne zwierzę nie ma chyba w języku polskim nazwy o równie szerokim polu semantycznym i negatywnej konotacji” (Peisert 2003: 150).

Tylko w trzech związkach, dwu polskich i jednym słoweńskim, świnia (w jednym związku też prosię jako element wymienny) przedstawiona jest pozytywnie: polskie ktoś jest trzérwy jak świnia, trzeźwy jak świnia, szczęśliwy jak świnia (prosię) w deszcz, słoweńskie: imeti svinjsko srečo, tj. mieć świńskie szczęście. Pozytywny obraz świni możemy dostrzec też w symbolice. Skarbonka często ma postać dobrze utuczonej świnki i oznacza fortunę, dobrobyt.

W języku polskim najczęściej używane są następujące określenia członków rodziny świni: osobniki dorosłe to świnia, wieprz, knur, tucznik, młode to prosię, prosiak, wieprzek, świniak, warchlak, ze zdrobnień zaś używa się świnka, prosiątko. W języku słoweńskim występuje natomiast więcej określeń: svinja, prasica, prašička, prašič, merjasec na określenie osobników dorosłych, młode to: prašiček, pujsek oraz dodatkowo określenia prašiča, nacechowane ekspresywnie, np. prase, prasec, prašiček, czy pieszczotliwie: pujs, pujsek i pieszczotliwa nazwa świni: pujsa. Z porównania analizowanych polskich i słoweńskich związków wyrazowych wynika, że najwięcej zarówno polskich, jak i słoweńskich związków zawiera komponent świnia - svinja.

W języku polskim świnia jest bardzo często podstawą wielu wyrazów pochodnych, o znaczeniu potwierdzającym jej negatywne cechy, np. świnić (się), naświnić, poświnić (sie), uświnić (sie), wyświnić (sie), zaświnić (sie), świntuszyć, naświntuszyć, wyświntuszyć, w znaczeniu ogólnym brudzić siebie, innych, okolicę, często niechcący, przez nieuwagę, śmiecić w jakimś miejscu, czy świntuch, świntucha, świntuszek, świntuszka 'o osobie brudnej, niechlujnej' lub 'osoba mówiąca rzeczy nieprzyzwoite', świntuszyć 'mówić o rzeczach uważanych za nieprzyzwoite, głównie związanych z seksem', świństwo, świństewko 'nieuczciwy postępek', świństwa 'słowa nieprzyzwoite lub wulgarne', świński, świniowaty, po świńsku itp. Podobnie w języku słoweńskim znajdziemy wyrazy pochodne od podstawy svinja, choć jest ich znacznie mniej niż w języku polskim, np. svinjarija 'świństwo', svinjak 'chlew', svinjariti 'świntuszyć', svinjati 'świnić', svinjski 'świński, cholerny'. W języku polskim funkcjonuje przymiotnik świński (świński dowcip), w słoweńskim zaś svinjski (svinjska šala) i prašičji (prašičja družina, tj. rodzina świni). Derywaty określające rodzaj mięsa pochodzącego ze świń to w języku polskim wieprzowina, rzadziej świnina w słoweńskim zaś svinjina. Wyraz świnia może być 
również podstawą nowych wyrazów, jak to się stało w przypadku świnalisty - wyrazu pochodzącego z socjolektu sportowego - oznaczającego finalistę, który osiąnnął zwycięstwo w nieuczciwy sposób.

Na podstawie frazeologizmów i luźnych związków wyrazowych w obu językach można wniosować, że stosunek Polaków i Słoweńców do świni jest w większości negatywny. Najprawdopodobniej stosunek ten związany jest ze sposobem życia, który wiodą te zwierzęte, czy trafniej ze sposobem, który zgotował im człowiek, a więc brudne środowisko i ciagłe karmienie w celu uzyskania dużej tuszy. Na podstawie wymienionych tutaj cech świni ludzie zaczęli używać wyrazów świnia, wieprz, prosię; svinja, prašič, prase itp. na opisywanie negatywnego zachowania u ludzi w ogóle, a więc również cech, których nie można przypisać zwierzętom, na przykład podłość, nikczemność, niemoralność. Taki właśnie obraz świni, potwierdzony frazeologizmami, metaforami i derywatami można znaleźć w języku polskim i słoweńskim, jak i zapewne w innych językach nie tylko słowiańskich.

\section{LITERATURA}

Keber, Janez. 1996. Živali v prispodobah. 1. in 2. del. Celje: Mohorjeva družba.

Peisert, Maria. 2003. Sus domesticus - zwierzę, którego nazwy używać nie wypada. W: Język a kultura. Opozycja homo-animal w języku i kulturze. t. 15. Dąbrowska, Anna (red.). Wrocław: Wydawnictwo Uniwersytetu Wrocławskiego. 149-155.

Tokarski, Ryszard. 1999. Językowy obraz świata w metaforach potocznych. W: Językowy obraz świata. Bartmiński, Jerzy (red.). Lublin: Wydawnictwo Marii Curie-Skłodowskiej. 6581.

\section{SŁOWNIKI}

Slovar slovenskih frazemov. 2011. Keber, Janez (red.). [wyd. 1]. Ljubljana: Založba ZRC, ZRC SAZU. [SSF]

Slovar slovenskega knjižnega jezika. 1994. [wyd. 1]. Ljubljana: Državna založba Slovenije. [SSKJ]

Stownik frazeologiczny języka polskiego. 1985. Skorupka, Stanisław (red.) t. I-II. [wyd. 4]. Warszawa: Wiedza Powszechna. [SFJP]

Stownik mitów i tradycji kultury. 1985. Kopaliński,Władysław (red.). [wyd. 6]. Warszawa: Państwowy Instytut Wydawniczy. [SMTK]

Uniwersalny stownik języka polskiego. 2008. Dubisz, Stanisław (red.). t. I-IV. [wyd. 2]. Warszawa: Wydawnictwo Naukowe PWN. [USJP] 


\section{SAŽETAK}

\section{JEZIKOVNA PODOBA SVINJE IN NJENE DRUŽINE SKOZI PRIZMO FRAZEOLOGIJE V POLJSKEM IN SLOVENSKEM JEZIKU}

Predmet obravnave prispevka so poljski in slovenski primerjalni frazemi, in sicer predvsem tisti s sestavino świnia/svinja oz. tisti, pri katerih kot sestavina nastopajo drugi predstavniki prašičje družine. Kot rezultat obravnave omenjenih frazemov je bilo ugotovljeno, katere lastnosti človek pripisuje svinji oz. drugim članom te živalske družine. Primerjava je pokazala tudi, kateri frazemi so v obeh jezikih isti ali podobni na izrazni in/ali pomenski ravni ter kakšne so razlike $\mathrm{v}$ njihovi rabi.

Ključne besede: primerjalni frazemi, didaktika poljščine kot drugega/tujega jezika, poljščina kot tuji jezik, slovenščina 
